\title{
Influence of ozonated water sanitation on postharvest quality of conventionally and organically cultivated mangoes after postharvest storage
}

\author{
Kamila de Almeida Monaco ${ }^{a}$, Sergio Marques Costa ${ }^{a}$, Igor Otavio Minatel ${ }^{\mathrm{a}}$, \\ Camila Renata Correa ${ }^{\mathrm{b}}$, Francisco Artés Calero ${ }^{\mathrm{c}}$, Fabio Vianello ${ }^{\mathrm{d}}$, \\ Giuseppina Pace Pereira Lima, ${ }^{\mathrm{a}, *}$ \\ ${ }^{a}$ Department of Chemistry and Biochemistry, IB, São Paulo State Universtity, Botucatu, São Paulo, Brazil \\ ${ }^{\mathrm{b}}$ Faculty of Medicine, São Paulo State Universtity, Botucatu, São Paulo, Brazil \\ c Grupo de Postrecolección y Refrigeración. Departamento de Ingeniería de Alimentos, Universidad Politécnica de Cartagena, Spain \\ ${ }^{\mathrm{d}}$ Department of Comparative Biomedicine and Food Science, University of Padua, Padova, Italy
}

\section{A R T I C L E I N F O}

Article history:

Received 2 February 2016

Received in revised form 12 May 2016

Accepted 13 May 2016

Available online 11 June 2016

\section{Keywords:}

Antioxidants

$\beta$-Carotene

Vitamin C

Physicochemical changes

\section{A B S T R A C T}

We investigated the alterations on bioactive compounds after treatments with ozonated water during the storage of organically and conventionally cultivated mangoes, cv. Palmer. Mangoes were stored in a cold chamber $\left(14 \pm 2{ }^{\circ} \mathrm{C}\right)$ for $15 \mathrm{~d}$ and evaluated after the harvest and sanitization treatments (chlorine and ozonated water-10 and $20 \mathrm{~min}$ ) at 7 and $15 \mathrm{~d}$. To simulate the market, after $7 \mathrm{~d}$, mangoes were removed from cold storage and kept at room temperature $\left(27 \pm 2{ }^{\circ} \mathrm{C}\right)$ to --- ! > be analyzed following $4(7+4)$ and 8 $(7+8) \mathrm{d}$ at room temperature. The conventionally mango showed higher firmness, regardless of the sanitization system used. Ozonated water did not alter the levels of $\beta$-carotene, ascorbic acid, dehydroascorbic acid and phenol in organically or conventionally cultivated mangoes during storage, but when the mangoes, cv. Palmer were transferred to room temperature, the $\beta$-carotene level increased. Organically cultivated mangoes showed higher levels of antioxidant activity. Ozonated water can be used as an alternative to chlorine sanitizer without causing damage to mango, cv. Palmer fruit or inducing a decrease in the various compounds and the treatment using ozonated water was efficient for maintaining fruit without microorganisms, preventing the reduction of quality and avoiding the generation of organic waste.

(c) 2016 Elsevier B.V. All rights reserved.

\section{Introduction}

Fruits are a rich source of antioxidant compounds such as vitamins (ascorbic acid, dehydroascorbic acid and $\beta$-carotene), vitamins precursors and polyphenols, and a high dietary intake of these compounds is associated with reduced disease (Krisetherton et al., 2002). Mango (Mangifera indica L.) is consumed worldwide, have increasing production rates and are of particular interest due to their nutritional value and remarkable taste. However, postharvest losses may occur due to several factors, but mostly because the postharvest life of mango usually does not exceed a few weeks and is limited by physiological deterioration of the fruit related to over-ripening, and by pathogen development

\footnotetext{
* Corresponding author.

E-mail addresses: gpplima@ibb.unesp.br, finalima@gmail.com (G.P.P. Lima).
}

leading to decay (González-Aguilar et al., 2001). For this reason, effective technologies are needed to ensure longer shelf-life and fruit quality, such as crop system management and methods of sanitization.

Organic crop cultivation has been reported to influence bioactive content. Some studies have shown that fruits and vegetables that are growing organically have a higher content of antioxidants (vitamin C, phenolic compounds, minerals, polyamines, among others) (Lima and Vianello, 2011; Hallmann and Rembial kowska, 2012). Nowadays, the demand for organic food is due to absence of agrochemicals residues that cause damage to health.

Ozone is a powerful oxidant that has been accepted as a food sanitizer, mainly in organic farming because it safely and spontaneously decomposes without forming hazardous residues (Ölmez and Kretzschmar, 2009). To sanitize vegetable foods, some products including chlorine gas, sodium or calcium hypochlorite 
and organic chlorine should be avoided because they form carcinogenic chlorinated compounds such as trihalomethanes that cause serious problems to human health and the environment (Yeoh et al., 2014). In this context, ozonated water has emerged as a safe form of sanitization in various plant products such as broccoli (Lima et al., 2014), honey pineapple, banana, and guava (Alothman et al., 2010), papaya (Yeoh et al., 2014).

Some studies have shown that the exposure of some fruits and vegetables to ozone increases the content of total phenols (González-Aguilar et al., 2007; Alothman et al., 2010; Yeoh et al., 2014) and other molecules with antioxidant activity (Lima et al., 2014). Ozone causes an oxidative action and in the plant may be harmful because of the production of free radicals. However, when sanitized with ozone, plant foods tend to have higher levels of antioxidant compounds as a way to protect the cell against damage promoted by reactive oxygen species (ROS) generated after sanitization (Minas et al., 2012).

\section{Materials and methods}

\subsection{Fruit}

Mango (Mangifera indica L., cv Palmer) fruit under conventional and organic cultivation were obtained from commercial orchards. Fruit produced in an organic system were harvested in Borborema city, São Paulo state (latitude $21^{\circ} 37^{\prime} 11^{\prime \prime} \mathrm{S}$, longitude $49^{\circ} 04^{\prime} 25^{\prime \prime} \mathrm{W}$, $429 \mathrm{~m}$ altitude) and those produced in the conventional system were harvested in Taquaritinga city, São Paulo state (latitude $21^{\circ}$ $24^{\prime} 23^{\prime \prime} \mathrm{S}$, longitude $48^{\circ} 30^{\prime} 20^{\prime \prime} \mathrm{W}, 579 \mathrm{~m}$ altitude).

The soil at both sites was subject to routine chemical analysis (Embrapa, 1997). The analysis results presented the following characteristics (organic farm): $\mathrm{pH}\left(\mathrm{CaCl}_{2} 0.01 \mathrm{~mol} \mathrm{~L}^{-1}\right) \quad 5.5$; $11.0 \mathrm{~kg} \mathrm{~m}^{-3}$ of organic material (OM); $35.0 \mathrm{~g} \mathrm{~m}^{-3}$ phosphorus (P); $0.47 \mathrm{~g} \mathrm{~kg}^{-1} \mathrm{H}+\mathrm{Al} ; 0.09 \mathrm{~g} \mathrm{~kg}^{-1}$ potassium (K); $0.54 \mathrm{~g} \mathrm{~kg}^{-1}$ calcium (Ca); $0.07 \mathrm{~g} \mathrm{~kg}^{-1}$ magnesium (Mg); $1.41 \mathrm{~g} \mathrm{~kg}^{-1}$ sum of bases (SB); $1.88 \mathrm{~g} \mathrm{~kg}^{-1}$ cation exchange capacity (CEC); base saturation (V) of $74.0 \%$. The micronutrient levels found were $25.0 \mathrm{~g} \mathrm{~m}^{-3}$ sulfur (S); $0.3 \mathrm{~g} \mathrm{~m}^{-3}$ boron (B); $3.8 \mathrm{~g} \mathrm{~m}^{-3}$ copper (Cu); $18 \mathrm{~g} \mathrm{~m}^{-3}$ iron (Fe); $3.4 \mathrm{~g} \mathrm{~m}^{-3}$ manganese (Mn) and $2.7 \mathrm{~g} \mathrm{~m}^{-3}$ zinc ( $\left.\mathrm{Zn}\right)$.

At the farm with the conventional system, the following soil characteristics were found: $\mathrm{pH}\left(\mathrm{CaCl}_{2} \quad 0.01 \mathrm{~mol} \mathrm{~L}^{-1}\right) \quad 5.4$; $12.0 \mathrm{~kg} \mathrm{~m}^{-3} \mathrm{OM} ; 78.0 \mathrm{~g} \mathrm{~m}^{-3} \mathrm{P} ; 0.74 \mathrm{~g} \mathrm{~kg}^{-1} \mathrm{H}+\mathrm{Al} ; 0,05 \mathrm{~g} \mathrm{~kg}^{-1} \mathrm{~K}$; $1.05 \mathrm{~g} \mathrm{~kg}^{-1} \mathrm{Ca} ; 0.23 \mathrm{~g} \mathrm{~kg}^{-1} \mathrm{Mg} ; 1.13 \mathrm{~g} \mathrm{~kg}^{-1} \mathrm{SB} ; 1.84 \mathrm{~g} \mathrm{~kg}^{-1} \mathrm{CEC} ; \mathrm{V}$ of $60.7 \%$. For the micronutrients, the levels found were: $0.68 \mathrm{~g} \mathrm{~m}^{-3} \mathrm{~B}$; $19.1 \mathrm{~g} \mathrm{~m}^{-3} \mathrm{Cu} ; 20 \mathrm{~g} \mathrm{~m}^{-3} \mathrm{Fe} ; 23.7 \mathrm{~g} \mathrm{~m}^{-3} \mathrm{Mn}$ and $3.5 \mathrm{~g} \mathrm{~m}^{-3} \mathrm{Zn}$.

\subsection{Sampling and preparation of the samples}

To ensure a fair comparison, organic and conventional mangoes at the same physiological age and with maturity index 2 (hard consistency, green peel color and light cream pulp) were used. After harvest, 120 fruit from each cultivation system were selected and submitted to 3 different sanitization methods. The fruit was either soaked for $10 \mathrm{~min}$ in distilled water containing Tween-20 (control), or soaked for $5 \mathrm{~min}$ in tap water containing $1 \%$ of sodium hypochlorite $\left(400 \mu \mathrm{LL}^{-1}\right)$, or soaked in ozonated water using an ozonizer (Degradatox/OZ Engineering, Industries LTD Equipment Ozone-generator, Porto Alegre, Brazil) that could generate approximately $1 \mathrm{mg} \mathrm{L}^{-1} \mathrm{~s}^{-1}$ in a $180 \mathrm{~L}$ tank. The ozonated mangoes were divided into two groups based on the time of immersion (10 or $20 \mathrm{~min}$ ). Mangoes were air-dried at room temperature for $60 \mathrm{~min}$.

The fruit were stored in a cold room at $14 \pm 2{ }^{\circ} \mathrm{C}$ and with $90 \pm 2 \%$ air humidity. Assays were conducted at day 0 (immediately after sanitization) and after 7 and $15 \mathrm{~d}$ of storage. To simulate market conditions, after $7 \mathrm{~d}$ in cold storage, the fruit were brought to room temperature and analyzed on day $4(7+4)$ and $8(7+8)$ after storage at room temperature $\left(27 \pm 2{ }^{\circ} \mathrm{C}\right.$ and $65 \pm 5 \%$ air humidity). Fruit stored for $15 \mathrm{~d}$ in the cold room were at the limit of market conditions and were therefore not submitted to holding at room temperature.

To measure the ascorbic acid, total phenolics, total flavonoids, $\beta$-carotene, DPPH and FRAP radical scavenging activity, the pulp was immediately was powdered by an analytical mill (IKA, A11) with liquid nitrogen and stored at $-80^{\circ} \mathrm{C}$.

\subsection{Firmness, $p H$, titratable acidity and total soluble solids}

The firmness (F) of the fruit pulp was determined using a manual digital penetrometer with an $8 \mathrm{~mm}$ probe (model 53205, Turoni, Italy) on the equatorial region of two fruit. The $\mathrm{pH}$ was measured in pulp mango juice (Ultra-Turrax for $5 \mathrm{~min}$ at $7500 \mathrm{rpm}$ ), using a pH meter (model HI 4221, Hanna Instruments Brazil). The titratable acidity (TA) of the fruit pulp was determined by the AOAC 942.15 method (1997) using $0.1 \mathrm{~mol} \mathrm{~L}^{-1} \mathrm{NaOH}$ and two to three drops of $0.1 \%(\mathrm{w} / \mathrm{v})$ phenolphthalein as an indicator, and the results were expressed as\% malic acid. The total soluble solid (TSS) in the filtered mango pulp juice was determined using a digital refractometer (Atago RX5000, Atago Co. Ltd., Itabashi-Ku, Tokyo, Japan), and the results were expressed in\%.

\subsection{Ascorbic acid and dehydroascorbic acid}

The levels of ascorbic acid (AA) and dehydroascorbic acid (DHAA) were measured as described by Pertuzatti et al. (2015), with minor modifications. Fifty milligrams of mango pulp were placed in a $15 \times 120 \mathrm{~mm}$ test tube and overlaid with $5 \mathrm{~mL}$ of cold extraction solution. This solution consisted of $10 \mathrm{~g}$ of metaphosphoric acid (4.5\% in ultrapure water) and $40 \mathrm{~mL}$ of glacial acetic acid. The tubes were vortexed for $2 \mathrm{~min}$ and incubated for $30 \mathrm{~min}$ in an ultrasonic bath at $5{ }^{\circ} \mathrm{C}$. The test tubes were then centrifuged at $4500 \mathrm{~g}$ (Hettich Zentrifugen, Mikro220R) for $15 \mathrm{~min}$ and supernatant transferred to amber flasks. The residue was twice subjected to similar procedures of extraction, and the supernatants obtained from three separate extractions were combined to reach a final volume of $15 \mathrm{~mL}$. After that, the sample was transferred to a $1.5 \mathrm{~mL}$ vial, and $20 \mu \mathrm{L}$ of the sample were injected into a UHPLC system (Ultimate 3000, Dionex-Thermo Scientific, USA) equipped with a diode array detector with an Ace 5 C18 (Advanced Chromatography Technologies, UK) column $(5 \mu \mathrm{m}, 250 \times 4.6 \mathrm{~mm})$. The mobile phase used was $2 \%$ acetic acid in an isocratic flow of $0.5 \mathrm{~mL} \mathrm{~min}^{-1}$. The column temperature was set to $25^{\circ} \mathrm{C}$, and the detection wavelength was $248 \mathrm{~nm}$ for the ascorbic acid and $240 \mathrm{~nm}$ for the dehydroascorbic acid. The results were expressed in $\mathrm{mg} \mathrm{kg}^{-1}$ of sample.

\subsection{Total polyphenolic (TP)}

The total polyphenolic content was analyzed using a spectrophotometric method, with Folin-Ciocalteu used as the reagent (Singleton and Rossi, 1965). Pulp (0.1 g) was extracted with $10 \mathrm{~mL}$ of a mixture of methanol:water $(80: 20 ; \mathrm{v} / \mathrm{v})$, kept in an ultrasonic bath for $30 \mathrm{~min}$ and centrifuged at $6000 \mathrm{~g}$ (Hettich Zentrifugen, Mikro220R) for $10 \mathrm{~min}$ at $4{ }^{\circ} \mathrm{C}$. The supernatant was collected, the precipitate was re-extracted and the supernatants were combined. The methanolic extract $0.5 \mathrm{~mL}$ was added to $0.5 \mathrm{~mL}$ Folin-Ciocalteu reagent in test tubes, and it was vortexed for $1.5 \mathrm{~min}$. The reaction mixture was added to $1 \mathrm{~mL}$ of saturated sodium carbonate solution $(25 \%, \mathrm{w} / \mathrm{v})$. The reaction mixture was incubated in the dark for $1 \mathrm{~h}$ at room temperature, and the absorbance was read at $760 \mathrm{~nm}$. The TP content was expressed as\% of gallic acid equivalent per mass of 
lyophilized tissue. All of the measurements were evaluated in triplicate.

\section{6. $\beta$-carotene}

The extract was prepared from $100 \mathrm{mg}$ of fresh mango in $5 \mathrm{~mL}$ of methanol. The tubes were vortexed for $30 \mathrm{~s}$ and then centrifuged at $3500 \mathrm{~g}$ at $4^{\circ} \mathrm{C}$ for $10 \mathrm{~min}$. The supernatant was removed, and $10 \mathrm{~mL}$ of THF (Tetrahydrofuran, of high-performance liquid chromatographic (HPLC) grade) (Sigma-Aldrich) were added, vortexed for $30 \mathrm{~s}$, centrifuged $\left(3500 \mathrm{~g}\right.$ and $\left.4{ }^{\circ} \mathrm{C}\right)$ for $10 \mathrm{~min}$, and the supernatant was removed. This procedure was repeated three more times until a volume of $25 \mathrm{~mL}$ was obtained. Afterward, the extract was dried in a nitrogen line and resuspended in $200 \mu \mathrm{L}$ of ethanol, and $20 \mu \mathrm{L}$ were injected in the HPLC (UltiMate $3000^{\mathrm{TM}}$ UHPLC systems, Thermo Scientific) with an Acclaim C30 column ( $3 \mu \mathrm{m}, 150 \times 4.6 \mathrm{~mm}$, Thermo Scientific, CA, USA). The mobile phase and HPLC conditions were the same as those previously described by Li et al. (2009). The results were expressed in $\mathrm{mg} \mathrm{kg}^{-1}$. All of the samples were analyzed in duplicate.

\subsection{Determination of the total antioxidant capacity}

The antioxidant capacity was measured using the DPPH $(1,1-$ Diphenyl-2-picrylhydrazyl) radical methods given by BrandWilliams et al. (1995), and the results were converted into percentage of antioxidant activity. DPPH solution was prepared with $2 \times 10^{-4} \mathrm{~g} \mathrm{~mL}^{-1}(0.010 \mathrm{mg}$ of DPPH with $50 \mathrm{~mL}$ of ethanol $99.8 \%$, both are Sigma-Aldrich). For extraction, $1 \mathrm{~g}$ of fresh matter was diluted with $10 \mathrm{~mL}$ of ethanol and centrifuged at $2000 \mathrm{~g}$ at $5{ }^{\circ} \mathrm{C}$ for $10 \mathrm{~min}$ (Hettich Mikro 220R). Readings were performed at $517 \mathrm{~nm}$, and absorbance was converted to the percentage of antioxidant activity using the following equation:

\% Reduced DPPH $=[$ (blank absorbance - sample absorbance $) \div$ blank absorbance] $\times 100$

A calibration curve was prepared with $20,40,80,120$ and $160 \mu \mathrm{mol}$ of Trolox (6-hydroxy-2,5,7,8-tetramethylchroman-2carboxylic acid) and the results were expressed as $\mu \mathrm{mol} \mathrm{\textrm {kg } ^ { - 1 }}$ trolox equivalents on a fresh weight basis.

The antioxidant activity was also determined using a FRAP (Ferric Reducing Ability of Plasma) test according to the method described by Benzie and Strain (1999). All of the measurements were evaluated in triplicate. The fresh FRAP reagent was prepared daily by mixing $25 \mathrm{~mL}$ acetate buffer (300 mmol, pH 3.6), $2.5 \mathrm{~mL}$ TPTZ solution (ferric 2,4,6-Tripyridyl-s-Triazine) (10 mmol in $40 \mathrm{mmol} \mathrm{HCl})$ and $2.5 \mathrm{~mL}$ of $\mathrm{FeCl}_{3} 6 \mathrm{H}_{2} \mathrm{O}(20 \mathrm{mmol})$ at $37^{\circ} \mathrm{C}$. In cuvettes, $900 \mu \mathrm{L}$ were placed and the initial absorbance was read and $100 \mu \mathrm{L}$ of sample was added and the absorbance was determined after $30 \mathrm{~min}$ at $595 \mathrm{~nm}$. It was used for calibration an aqueous solution of $\mathrm{FeSO}_{4} \cdot 7 \mathrm{H}_{2} \mathrm{O}(0-1 \mathrm{mmol})$ and the results were expressed as $\mathrm{mmol} \mathrm{kg}^{-1}$ of $\mathrm{Fe}^{+2}$.

\subsection{Microbiological analysis}

Microbiological analyses were conducted on two fruit from each treatment group after harvest, after $7 \mathrm{~d}$ and $15 \mathrm{~d}$ of refrigeration and at simulated marketing. The fruit were pulverized in liquid nitrogen, and an aliquot of $25 \mathrm{~g}$ was resuspended in $225 \mathrm{~mL}$ of sterile saline peptone solution (0.1\%). The fruit suspensions were diluted for $20 \mathrm{~min}$ in a $0.1 \mathrm{M}$ sodium phosphate buffer with $\mathrm{pH} 7.0$ that was previously sterilized at $121^{\circ} \mathrm{C}$ and at $1 \mathrm{~atm}$ and inoculated into a culture media for the verification of the presence of fungi and bacteria. All of the tests were performed in triplicate as described by Manafi (2000).
To detect Staphylococcus aureus and Salmonella sp., the fruit extract aliquots $(100 \mu \mathrm{L})$ were inoculated in Petri dishes containing Staphylococcus agar no110 (Himedia) and Salmonella Agar Shigella M108 (Himedia). To detect Salmonella, the presence or absence of colonies of $S$. aureus were estimated using a direct-counting technique.

To detect the Total Coliforms and Thermotolerant Coliform, the most probable number (MPN) method was used. The presumptive test was performed by distributing, in triplicate, extract aliquots $(100 \mu \mathrm{L})$ in inverted Durham tubes containing sodium lauryl sulphate broth (LST), which were incubated at $35^{\circ} \mathrm{C}$ for $48 \mathrm{~h}$. The tubes showing turbidity and gas evolution were considered as positive for the presence of total coliforms. Aliquots of those positive cultures $(100 \mu \mathrm{L})$ were then seeded into inverted. All of resultant readings were expressed as most probable number of bacteria per gram of analyzed material $\left(\mathrm{MPN} \mathrm{g}^{-1}\right)$.

The test was considered exempted when the result of total coliforms and thermotolerant coliform were $<3$ and $S$. aureus $<100$. Salmonella was only checked for the presence or absence.

\subsection{Experimental design and statistical analysis}

The design was totally random with a factorial scheme of $5 \times 8$ (evaluation days $\times$ treatments) with 3 repetitions and two samples per repetition. All of the analyses were conducted in triplicate. The Scott-Knott test at a $5 \%$ probability was used to compare the means.

\section{Results and discussion}

\subsection{Firmness, pH, titratable acidity and soluble solids}

There was an increase in $\mathrm{pH}$ with storage time (after harvest), and the $\mathrm{pH}$ increased when the fruit was transferred to room temperature when simulating marketing $(7+4$ and $7+8 \mathrm{~d})$ (Table 1), especially for the organic mangoes. $\mathrm{pH}$ increased with ripening, however, irrespective of the cultivation system, the $\mathrm{pH}$ of the mangoes was not influenced by chlorine or ozone.

At 7 th $\mathrm{d}$ in cold storage, the conventional mango fruit were firmer than the organic fruit regardless of the sanitization system used (Table 1). After that period, the firmness of all of the mango fruit decreased. In the last stage of the commercial distribution simulation $(7+8 \mathrm{~d})$, the organic mangoes showed lower firmess values than those from the conventional system. In most of the treatments, fruit that were stored for $15 \mathrm{~d}$ in a cold chamber showed a degree of firmness similar to those found in fruit stored under refrigeration and those kept at room temperature during the commercialization simulation. Ozonated water did not affect this quality characteristic, even though it is an oxidizing agent. Other studies have shown that using sanitizing products such as ozone may result in increased firmness or not induce alterations (Rodoni et al., 2010; Aguayo et al., 2006).

The total soluble solids (TSS) increased with the time of storage of mangoes in the cold chamber, whether conventional or organic (Table 1). Ozonated water did not cause any alterations in the TSS content, although organic mangoes kept in cold storage (15 d) and treated with ozonated water and chlorine showed higher values than conventional the mangoes, regardless of the time of immersion (10 or $20 \mathrm{~min}$ ). Sanitization with ozone also increases TSS in other fruits (Tzortzakis et al., 2007; Ali et al., 2014; Yeoh et al., 2014). On the other hand, when the mangoes were left at room temperature to simulate commercialization, this tendency disappeared. This may be attributable to the action of temperature, which increased respiratory metabolism and promoted the formation of TSS from storage compounds. These results were found for both organic and conventional mangoes, which shows 
Table 1

Physicochemical characteristics during the postharvest of organic and conventional mango, cv. Palmer fruit sanitized with ozonated water ( $\mathrm{n}=\mathrm{X} \pm \mathrm{SD}$ ).

\begin{tabular}{|c|c|c|c|c|c|c|c|}
\hline & & \multirow[t]{2}{*}{ Treatments } & \multirow[t]{2}{*}{ Post harvest } & \multicolumn{2}{|c|}{ Cold storage (days post-harvest) } & \multicolumn{2}{|c|}{ Simulated marketing (days post-harvest) } \\
\hline & & & & 7 & 15 & $7+4$ & $7+8$ \\
\hline \multirow[t]{8}{*}{$\mathrm{pH}$} & Conv & W & $3.5 \pm 0.1^{\mathrm{Eb}^{*}}$ & $3.6 \pm 0.1^{\mathrm{Da}}$ & $4.8 \pm 0.1^{\mathrm{Aa}}$ & $4.2 \pm 0.1^{\mathrm{Cc}}$ & $4.6 \pm 0.1^{\mathrm{Bc}}$ \\
\hline & & $\mathrm{C}$ & $3.4 \pm 0.01^{\mathrm{Db}}$ & $3.5 \pm 0.1^{\mathrm{Db}}$ & $4.3 \pm 0.1^{\mathrm{Bc}}$ & $4.0 \pm 0.1^{\mathrm{Cd}}$ & $4.8 \pm 0.1^{\mathrm{Ab}}$ \\
\hline & & $\mathrm{Oz}_{10}$ & $3.7 \pm 0.11^{\mathrm{Ca}}$ & $3.6 \pm 0.2^{\mathrm{Ca}}$ & $4.5 \pm 0.1^{\mathrm{Ab}}$ & $4.0 \pm 0.03^{B d}$ & $4.6 \pm 0.1^{\mathrm{Ac}}$ \\
\hline & & $\mathrm{Oz}_{20}$ & $3.6 \pm 0.1^{\mathrm{Da}}$ & $3.4 \pm 0.03^{\mathrm{Eb}}$ & $4.2 \pm 0.1^{\mathrm{Cd}}$ & $4.4 \pm 0.2^{\mathrm{Bb}}$ & $4.7 \pm 0.04^{\mathrm{Ab}}$ \\
\hline & Org & W & $3.4 \pm 0.03^{\mathrm{Db}}$ & $3.4 \pm 0.1^{\mathrm{Db}}$ & $4.2 \pm 0.04^{\mathrm{Cc}}$ & $4.6 \pm 0.03^{\mathrm{Ba}}$ & $4.8 \pm 0.2^{\mathrm{Ab}}$ \\
\hline & & $\mathrm{C}$ & $3.3 \pm 0.1^{\mathrm{Ec}}$ & $3.4 \pm 0.01^{\mathrm{Db}}$ & $4.1 \pm 0.03^{\mathrm{Cd}}$ & $4.7 \pm 0.1^{\mathrm{Ba}}$ & $5.0 \pm 0.03^{\mathrm{Aa}}$ \\
\hline & & $\mathrm{Oz}_{10}$ & $3.3 \pm 0.03^{\mathrm{Dc}}$ & $3.4 \pm 0.04^{\mathrm{Db}}$ & $4.4 \pm 0.1^{\mathrm{Cc}}$ & $4.7 \pm 0.1^{\mathrm{Ba}}$ & $4.9 \pm 0.04^{\mathrm{Aa}}$ \\
\hline & & $\mathrm{Oz}_{20}$ & $3.4 \pm 0.04^{\mathrm{Db}}$ & $3.5 \pm 0.03^{\mathrm{Db}}$ & $4.3 \pm 0.1^{\mathrm{Cc}}$ & $4.5 \pm 0.1^{\mathrm{Bb}}$ & $5.0 \pm 0.04^{\mathrm{Aa}}$ \\
\hline \multirow[t]{8}{*}{$\mathrm{F}(\mathrm{N})$} & Conv & W & $160.1 \pm 2.2^{\mathrm{Ab}}$ & $165.7 \pm 16.8^{\mathrm{Ab}}$ & $30.9 \pm 3.2^{\mathrm{Cc}}$ & $68.3 \pm 5.8^{\mathrm{Ba}}$ & $21.6 \pm 1.4^{\mathrm{Cb}}$ \\
\hline & & $C$ & $136.4 \pm 3.1^{\mathrm{Ac}}$ & $144.2 \pm 4.5^{\mathrm{Ad}}$ & $47.0 \pm 1.8^{\mathrm{Ba}}$ & $51.0 \pm 3.2^{\mathrm{Bb}}$ & $23.0 \pm 4.6^{\mathrm{Cb}}$ \\
\hline & & $\mathrm{Oz}_{10}$ & $155.6 \pm 1.4^{\mathrm{Bb}}$ & $180.0 \pm 4.5^{\mathrm{Aa}}$ & $24.1 \pm 3.7^{\mathrm{Cd}}$ & $29.2 \pm 3.0^{\mathrm{Cc}}$ & $31.0 \pm 4.5^{\mathrm{Ca}}$ \\
\hline & & $\mathrm{Oz}_{20}$ & $155.9 \pm 4.7^{\mathrm{Ab}}$ & $155.4 \pm 7.0^{\mathrm{Ac}}$ & $22.7 \pm 9.0^{\mathrm{Cd}}$ & $35.8 \pm 7.6^{\mathrm{Bc}}$ & $17.7 \pm 2.5^{\mathrm{Cb}}$ \\
\hline & Org & W & $165.3 \pm 5.5^{\mathrm{Ab}}$ & $151.0 \pm 4.2^{\mathrm{Bd}}$ & $17.7 \pm 1.6^{\mathrm{Cd}}$ & $23.8 \pm 3.2^{\mathrm{Cd}}$ & $19.5 \pm 4.1^{\mathrm{Cb}}$ \\
\hline & & $\mathrm{C}$ & $138.9 \pm 10.1^{\mathrm{Ac}}$ & $135.2 \pm 9.4^{\mathrm{Ae}}$ & $31.7 \pm 5.99^{\mathrm{BC}}$ & $19.3 \pm 6.1^{\mathrm{Cd}}$ & $11.2 \pm 3.6^{\mathrm{Cc}}$ \\
\hline & & $\mathrm{Oz}_{10}$ & $181.6 \pm 4.6^{\mathrm{Aa}}$ & $131.1 \pm 2.1^{\mathrm{Be}}$ & $25.85 \pm 1.1^{\mathrm{Cd}}$ & $28.8 \pm 7.4^{\mathrm{Cc}}$ & $11.3 \pm 6.8^{\mathrm{Dc}}$ \\
\hline & & $\mathrm{Oz}_{20}$ & $154.6 \pm 6.8^{\mathrm{Ab}}$ & $117.7 \pm 6.3^{\mathrm{Bf}}$ & $35.4 \pm 2.3^{\mathrm{Db}}$ & $52.0 \pm 2.5^{\mathrm{Cb}}$ & $8.8 \pm 2.8^{\mathrm{Ec}}$ \\
\hline \multirow[t]{8}{*}{ TSS (\%) } & Conv & W & $6.8 \pm 0.3^{\mathrm{Da}}$ & $8.9 \pm 0.1^{\mathrm{Cd}}$ & $14.7 \pm 0.1^{\mathrm{Bb}}$ & $15.4 \pm 0.1^{\mathrm{Aa}}$ & $15.6 \pm 0.8^{\mathrm{Aa}}$ \\
\hline & & $\mathrm{C}$ & $6.6 \pm 0.5^{\mathrm{Da}}$ & $9.4 \pm 0.3^{\mathrm{Cc}}$ & $15.0 \pm 0.1^{\mathrm{Ab}}$ & $13.5 \pm 0.3^{\mathrm{Bb}}$ & $13.7 \pm 0.7^{\mathrm{Bc}}$ \\
\hline & & $\mathrm{Oz}_{10}$ & $6.5 \pm 0.3^{\mathrm{Da}}$ & $6.1 \pm 0.6^{\mathrm{Df}}$ & $14.1 \pm 0.8^{\mathrm{Cc}}$ & $15.3 \pm 0.1^{\mathrm{Ba}}$ & $16.1 \pm 0.6^{\mathrm{Aa}}$ \\
\hline & & $\mathrm{Oz}_{20}$ & $7.0 \pm 0.7^{\mathrm{Da}}$ & $8.1 \pm 0.5^{\mathrm{Ce}}$ & $15.0 \pm 0.3^{\mathrm{Ab}}$ & $15.4 \pm 0.3^{\mathrm{Aa}}$ & $14.3 \pm 0.3^{\mathrm{Bc}}$ \\
\hline & Org & W & $6.5 \pm 0.4^{\mathrm{Da}}$ & $10.7 \pm 0.5^{\mathrm{Cb}}$ & $15.4 \pm 0.2^{\mathrm{Ab}}$ & $12.4 \pm 0.5^{\mathrm{Bc}}$ & $15.0 \pm 0.8^{\mathrm{Ab}}$ \\
\hline & & $\mathrm{C}$ & $5.4 \pm 0.4^{\mathrm{Db}}$ & $10.9 \pm 0.4^{\mathrm{Cb}}$ & $16.4 \pm 0.4^{\mathrm{Aa}}$ & $15.3 \pm 0.2^{\mathrm{Ba}}$ & $15.9 \pm 0.5^{\mathrm{Aa}}$ \\
\hline & & $\mathrm{Oz}_{10}$ & $6.3 \pm 0.2^{\mathrm{Da}}$ & $9.8 \pm 0.7^{\mathrm{Cc}}$ & $17.2 \pm 0.1^{\mathrm{Aa}}$ & $14.1 \pm 0.6^{\mathrm{Bb}}$ & $14.3 \pm 0.1^{\mathrm{Bc}}$ \\
\hline & & $\mathrm{Oz}_{20}$ & $6.6 \pm 0.6^{\mathrm{Ea}}$ & $11.8 \pm 0.6^{\mathrm{Da}}$ & $16.8 \pm 0.6^{\mathrm{Aa}}$ & $16.0 \pm 0.1^{\mathrm{Ba}}$ & $12.9 \pm 0.6^{\mathrm{Cd}}$ \\
\hline \multirow[t]{7}{*}{ TA (\% galic acid) } & Conv & W & $1.4 \pm 0.3^{\mathrm{Bd}}$ & $1.9 \pm 0.03^{\mathrm{Ac}}$ & $0.6 \pm 0.02^{\mathrm{De}}$ & $0.9 \pm 0.1^{\mathrm{Cd}}$ & $0.5 \pm 0.1^{\mathrm{Dc}}$ \\
\hline & & $\mathrm{C}$ & $1.8 \pm 0.2^{\mathrm{Bb}}$ & $2.2 \pm 0.2^{\mathrm{Ab}}$ & $1.0 \pm 0.04^{\mathrm{Cc}}$ & $0.8 \pm 0.1^{\mathrm{Dd}}$ & $0.6 \pm 0.03^{\mathrm{Ec}}$ \\
\hline & & $\mathrm{Oz}_{10}$ & $1.5 \pm 0.1^{\mathrm{Bd}}$ & $1.7 \pm 0.6^{\mathrm{Ad}}$ & $1.2 \pm 0.01^{\mathrm{Cb}}$ & $1.0 \pm 0.1^{\mathrm{Dc}}$ & $0.6 \pm 0.02^{\mathrm{Ec}}$ \\
\hline & & $\mathrm{Oz}_{20}$ & $1.8 \pm 0.1^{\mathrm{Ab}}$ & $1.9 \pm 0.1^{\mathrm{Ac}}$ & $1.0 \pm 0.1^{\mathrm{Bc}}$ & $1.0 \pm 0.1^{\mathrm{Bc}}$ & $0.6 \pm 0.01^{\mathrm{Cc}}$ \\
\hline & Org & W & $1.6 \pm 0.01^{\mathrm{Bc}}$ & $0.7 \pm 0.1^{\mathrm{Ce}}$ & $1.9 \pm 0.01^{\mathrm{Aa}}$ & $0.6 \pm 0.02^{\text {De }}$ & $0.6 \pm 0.1^{\mathrm{Dc}}$ \\
\hline & & $C$ & $2.0 \pm 0.02^{\mathrm{Aa}}$ & $1.9 \pm 0.1^{\mathrm{Ac}}$ & $0.9 \pm 0.1^{\mathrm{Cd}}$ & $1.0 \pm 0.1^{\mathrm{Bc}}$ & $0.61 \pm 0.1^{\mathrm{Dc}}$ \\
\hline & & $\mathrm{Oz}_{10}$ & $0.7 \pm 0.03^{\mathrm{De}}$ & $2.8 \pm 0.1^{\mathrm{Aa}}$ & $0.8 \pm 0.01^{\mathrm{Cd}}$ & $1.6 \pm 0.1^{\mathrm{Bb}}$ & $0.81 \pm 0.1^{\mathrm{Cb}}$ \\
\hline
\end{tabular}

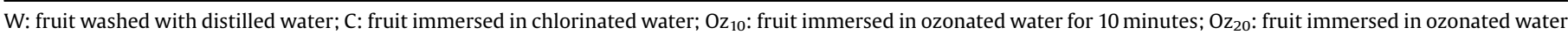
for 20 minutes. F: Firmness; SS: Soluble Solids; TA: Titratable Acidity.

The means followed by the same capital letters (lines) and case letters (column) were not statistically significant according to the Scott-Knott's test ( $\mathrm{P} \leq 0.05$ ).

that in this study the TSS in the mango fruit did not differ according to type of cultivation. Although the levels of total soluble solids exceeded the acceptable limits set by Brazilian law, which sets Quality and Identity Standards (PIQ) for mango pulp such as $11 \%$ (Brasil, 2000), these levels may vary depending on a variety of factors including cultivation, climate, soil and irrigation.

The organic mango fruit treated with ozonated water for $10 \mathrm{~min}$ after $7 \mathrm{~d}$ showed higher levels of titratable acidity (TA) (2.8\%), and there was a reduction resulting from the number of days in storage (Table 1 ). We noted a tendency for acidity to decrease with storage because of the respiratory process (Ali et al., 2014). This effect might be attributed to the use of organic acids as a reserve energy source for the cells.

\subsection{Bioactive compounds}

AA is the principal biologically active form of vitamin $C$, but DHAA, an oxidation product, also exhibits biological activity and can be easily converted into ascorbic acid in the human body. It is important to measure both AA and DHA in fruits and vegetables (Lee and Kader, 2000). The content of dehydroascorbic acid (DHAA) in the conventional and organic mangoes, cv. Palmer was much lower than that found for ascorbic acid in the rest of the experiment (Table 2). In cultivars of mango, including cv. Palmer, the values of dehydroascorbic acid vary from 10.3 to $17.7 \%$ (Ribeiro et al., 2008), although our results showed lower values of this acid when the mango, cv. Palmer fruit were stored in the cold chamber. During the simulated marketing, there was an increase in this compound, primarily in the fruit of conventional origin that were not sanitized with ozonated water.

From day 0 (after harvest) to day 7 , the mango fruit stored in the cold chamber showed no increase in their ascorbic acid (AA) content for most of the sanitizing treatments used, regardless of the type of cultivation (organic or conventional) (Table 2). When brought to room temperature $(7+4 \mathrm{~d})$, the fruit of mango, $\mathrm{cv}$. Palmer treated with ozonated water (organic or conventional) showed higher values compared with those washed only with water (control). However, at $7+8 \mathrm{~d}$, the levels of ascorbic acid in the conventional mangoes sanitized with ozonated water did not produce the same results. After exposure to gaseous ozone, strawberries showed decreased levels of AA at $12 \mathrm{~d}$ after storage (Allende et al., 2007). Moreover, with papayas, the ozone treatment increased the levels of AA (Ali et al., 2014), and this effect was attributed to alterations in the ascorbate peroxidase and ascorbate oxidase activity.

In the majority of the treatments, there was a decrease of ascorbic acid content after the transfer of the fruit from cold chamber to room temperature, which may be attributed to the degradative metabolism that occurs over ripening, induced by higher temperatures than in cold chambers (Lee and Kader, 2000). Interesting results were observed in organic and conventional mangoes. At $7+4 d$, the mangoes treated with sanitizers had higher AA levels than sanitized with water only. This difference disappears on the last day of analysis, because of the decline in fruit condition. 
Table 2

Effect of sanitation with chlorine or ozonated water on bioactive compounds during the postharvest of organic and conventional mango, $\mathrm{cv}$. Palmer ( $\mathrm{n}=\mathrm{X} \pm \mathrm{SD}$ ).

\begin{tabular}{|c|c|c|c|c|c|c|c|}
\hline & & \multirow[t]{2}{*}{ Treatments } & \multirow[t]{2}{*}{ Post harvest } & \multicolumn{2}{|c|}{ Cold storage (days postharvest) } & \multicolumn{2}{|c|}{ Simulated marketing (days postharvest) } \\
\hline & & & & 7 & 15 & $7+4$ & $7+8$ \\
\hline \multirow[t]{8}{*}{$\mathrm{AA}\left(\mathrm{g} \mathrm{kg}^{-1}\right)$} & Conv & $\mathrm{W}$ & $0.30 \pm 0.11^{\mathrm{Ba}^{*}}$ & $0.36 \pm 0.05 .2^{\mathrm{Bc}}$ & $0.38 \pm 0.02^{\mathrm{Bbc}}$ & $0.18 \pm 0.03^{\mathrm{Cd}}$ & $0.51 \pm 0.05^{\mathrm{Aa}}$ \\
\hline & & $\mathrm{C}$ & $0.14 \pm 0.05^{\mathrm{Bc}}$ & $0.54 \pm 0.01^{\mathrm{Ab}}$ & $0.47 \pm 0.05^{\text {Aab }}$ & $0.23 \pm 0.02^{\mathrm{Cd}}$ & $0.51 \pm 0.07^{\mathrm{Aa}}$ \\
\hline & & $\mathrm{Oz}_{10}$ & $0.26 \pm 0.09^{\mathrm{Bab}}$ & $0.28 \pm 0.04^{\mathrm{Bc}}$ & $0.27 \pm 0.02^{\mathrm{Bc}}$ & $0.62 \pm 0.04^{\mathrm{Aa}}$ & $0.36 \pm 0.14^{\mathrm{Bbc}}$ \\
\hline & & $\mathrm{Oz}_{20}$ & $0.16 \pm 0.02^{\mathrm{Dbc}}$ & $0.51 \pm 0.09^{\mathrm{ABb}}$ & $0.42 \pm 0.07^{\mathrm{BCab}}$ & $0.55 \pm 0.09^{\text {Aab }}$ & $0.35 \pm 0.04^{\mathrm{Cbc}}$ \\
\hline & Org & W & $0.29 \pm 0.09^{\mathrm{Ba}}$ & $0.55 \pm 0.06^{\mathrm{Ab}}$ & $0.29 \pm 0.06^{\mathrm{Bc}}$ & $0.12 \pm 0.05^{\mathrm{Cd}}$ & $0.25 \pm 0.05^{\mathrm{Bc}}$ \\
\hline & & $\mathrm{C}$ & $0.37 \pm 0.01^{\mathrm{BCa}}$ & $0.31 \pm 0.04^{\mathrm{Cc}}$ & $0.51 \pm 0.04^{\mathrm{Aa}}$ & $0.46 \pm 0.01^{\mathrm{Bb}}$ & $0.40 \pm 0.02^{\mathrm{BCab}}$ \\
\hline & & $\mathrm{Oz}_{10}$ & $0.323 \pm 0.01^{\mathrm{Ba}}$ & $0.70 \pm 0.06^{\mathrm{Aa}}$ & $0.39 \pm 0.04^{\mathrm{Bbc}}$ & $0.35 \pm 0.08^{\mathrm{Bc}}$ & $0.40 \pm 0.03^{\mathrm{Bab}}$ \\
\hline & & $\mathrm{Oz}_{20}$ & $0.31 \pm 0.05^{\mathrm{Ba}}$ & $0.58 \pm 0.04^{\mathrm{Ab}}$ & $0.49 \pm 0.03^{\mathrm{Aab}}$ & $0.50 \pm 0.09^{\text {Aab }}$ & $0.33 \pm 0.06^{\mathrm{Bbc}}$ \\
\hline \multirow[t]{8}{*}{ DHAA $\left(\mathrm{g} \mathrm{kg}^{-1}\right)$} & Conv & W & $0.01 \pm 0.003^{\mathrm{Da}}$ & $0.03 \pm 0.004^{\mathrm{Ca}}$ & $0.01 \pm 0.005^{\mathrm{CDa}}$ & $0.14 \pm 0.0039^{\mathrm{Aa}}$ & $0.06 \pm 0.008^{\mathrm{Bc}}$ \\
\hline & & $\mathrm{C}$ & $0.004 \pm 0.001^{\mathrm{Da}}$ & $0.02 \pm 0.003^{\mathrm{Cab}}$ & $0.02 \pm 0.003^{\mathrm{CDa}}$ & $0.15 \pm 13.7^{\mathrm{Aa}}$ & $0.10 \pm 0.008^{\mathrm{Ba}}$ \\
\hline & & $\mathrm{Oz}_{10}$ & $0.003 \pm 0.0^{\mathrm{Ba}}$ & $0.007 \pm 0.001^{\mathrm{Bbc}}$ & $0.02 \pm 0.001^{\mathrm{Ba}}$ & $0.03 \pm 0.008^{\mathrm{Ac}}$ & $0.05 \pm 0.008^{\mathrm{Ac}}$ \\
\hline & & $\mathrm{Oz}_{20}$ & $0.02 \pm 0.001^{\mathrm{Ba}}$ & $0.009 \pm 0.003^{\mathrm{Bbc}}$ & $0.009 \pm 0.00^{\mathrm{a}}$ & $0.06 \pm 0.009^{\mathrm{Ab}}$ & $0.05 \pm 0.01^{\mathrm{Ac}}$ \\
\hline & Org & $\mathrm{W}$ & $0.004 \pm 0.001^{\mathrm{Ca}}$ & n.d. & $0.02 \pm 0.007^{\mathrm{Ca}}$ & $0.05 \pm 0.006^{\mathrm{Bbc}}$ & $0.07 \pm 0.006^{\mathrm{Abc}}$ \\
\hline & & $\mathrm{C}$ & $0.007 \pm 0.003^{\mathrm{Ca}}$ & n.d. & $0.007 \pm 0.002^{\mathrm{Ca}}$ & $0.04 \pm 0.005^{\mathrm{Bc}}$ & $0.08 \pm 0.003^{\mathrm{Ab}}$ \\
\hline & & $\mathrm{Oz}_{10}$ & $0.002 \pm 0.0^{\mathrm{Ba}}$ & $0.003 \pm 0.003^{\mathrm{Bbc}}$ & $0.01 \pm 0.005^{\mathrm{Ba}}$ & $0.03 \pm 0.001^{\mathrm{Ac}}$ & $0.02 \pm 0.003^{\mathrm{Abc}}$ \\
\hline & & $\mathrm{Oz}_{20}$ & $0.006 \pm 0.001^{\mathrm{Ca}}$ & $0.001 \pm 0.0^{\mathrm{Cc}}$ & $0.005 \pm 0.0^{\mathrm{Ca}}$ & $0.04 \pm 4.8^{\mathrm{Bc}}$ & $0.07 \pm 0.006^{\mathrm{Abc}}$ \\
\hline \multirow[t]{8}{*}{$\beta$-carotene $\left(\mathrm{g} \mathrm{kg}^{-1}\right)$} & Conv & $\mathrm{W}$ & $0.02 \pm 0.007^{\mathrm{Cb}}$ & $0.08 \pm 0.03^{\mathrm{Ba}}$ & $0.10 \pm 0.004^{\mathrm{Ba}}$ & $0.03 \pm 0.005^{\mathrm{Cb}}$ & $0.18 \pm 0.001^{\mathrm{Ac}}$ \\
\hline & & $\mathrm{C}$ & $0.02 \pm 0.001^{\mathrm{Cb}}$ & $0.05 \pm 0.0^{\mathrm{Cb}}$ & $0.12 \pm 0.01^{\mathrm{Ba}}$ & $0.04 \pm 0.008^{\mathrm{Cb}}$ & $0.16 \pm 0.004^{\mathrm{Ac}}$ \\
\hline & & $\mathrm{Oz}_{10}$ & $0.02 \pm 0.0^{\mathrm{Bb}}$ & $0.04 \pm 0.01^{\mathrm{Bb}}$ & $0.05 \pm 0.006^{\mathrm{Bc}}$ & $0.05 \pm 0.004^{\mathrm{Bb}}$ & $0.12 \pm 0.002^{\mathrm{Ad}}$ \\
\hline & & $\mathrm{Oz}_{20}$ & $0.05 \pm 0.002^{\mathrm{Ba}}$ & $0.05 \pm 0.004^{\mathrm{Bb}}$ & $0.06 \pm 0.02^{\mathrm{Bb}}$ & $0.05 \pm 0.003^{\mathrm{Bb}}$ & $0.12 \pm 0.002^{\mathrm{Ad}}$ \\
\hline & Org & W & $0.05 \pm 0.004^{\mathrm{Aa}}$ & $0.05 \pm 0.001^{\mathrm{Ab}}$ & $0.07 \pm 0.009^{\mathrm{Ab}}$ & $0.05 \pm 0.009^{\mathrm{Ab}}$ & $0.07 \pm 0.004^{\mathrm{Ae}}$ \\
\hline & & $\mathrm{C}$ & $0.02 \pm 0.0^{\mathrm{Cb}}$ & $0.03 \pm 0.001^{\mathrm{Cb}}$ & $0.04 \pm 0.002^{\mathrm{Cc}}$ & $0.08 \pm 0.004^{\mathrm{Ba}}$ & $0.28 \pm 0.05^{\mathrm{Ab}}$ \\
\hline & & $\mathrm{Oz}_{10}$ & $0.042 \pm 0.004^{\mathrm{Ba}}$ & $0.02 \pm 0.003^{\mathrm{Bb}}$ & $0.04 \pm 0.005^{\mathrm{Bc}}$ & $0.05 \pm 0.002^{\mathrm{Bb}}$ & $0.16 \pm 0.05^{\mathrm{Ac}}$ \\
\hline & & $\mathrm{Oz}_{20}$ & $0.04 \pm 0.003^{\mathrm{Ba}}$ & $0.05 \pm 0.003^{\mathrm{Bb}}$ & $0.03 \pm 0.004^{\mathrm{Bc}}$ & $0.04 \pm 0.007^{\mathrm{Bb}}$ & $0.32 \pm 0.02^{\mathrm{Aa}}$ \\
\hline \multirow[t]{8}{*}{$\mathrm{TP}\left(\mathrm{g} \mathrm{kg}^{-1}\right)$} & Conv & W & $10.0 \pm 0.1^{\mathrm{Ab}}$ & $9.0 \pm 0.1^{\mathrm{Ba}}$ & $8.0 \pm 0.1^{\mathrm{Cb}}$ & $11.0 \pm 0.3^{\mathrm{Ab}}$ & $9.0 \pm 0.3^{\mathrm{Bb}}$ \\
\hline & & $\mathrm{C}$ & $8.0 \pm 0.3^{\mathrm{Bd}}$ & $8.0 \pm 0.1^{\mathrm{Bb}}$ & $8.0 \pm 0.1^{\mathrm{Cc}}$ & $9.0 \pm 0.3^{\mathrm{Ad}}$ & $9.0 \pm 0.1^{\mathrm{Ab}}$ \\
\hline & & $\mathrm{Oz}_{10}$ & $8 \pm 0.1^{\mathrm{Bd}}$ & $8.0 \pm 0.1^{\mathrm{Bb}}$ & $8.0 \pm 0.1^{\mathrm{Bb}}$ & $11.0 \pm 0.03^{\mathrm{Aa}}$ & $8.0 \pm 0.1^{\mathrm{Cd}}$ \\
\hline & & $\mathrm{Oz}_{20}$ & $16.0 \pm 1.0^{\mathrm{Aa}}$ & $8.0 \pm 0.1^{\mathrm{Db}}$ & $7.0 \pm 0.2^{\mathrm{Ec}}$ & $9.0 \pm 0.1^{\mathrm{Cd}}$ & $10.0 \pm 0.2^{\mathrm{Ba}}$ \\
\hline & Org & W & $9.0 \pm 0.2^{\mathrm{Ac}}$ & $6.0 \pm 0.2^{\mathrm{Ed}}$ & $7.0 \pm 0.2^{\mathrm{Cc}}$ & $9.0 \pm 0.2^{\mathrm{Be}}$ & $6.0 \pm 0.1^{\mathrm{Df}}$ \\
\hline & & $\mathrm{C}$ & $9.0 \pm 0.1^{\mathrm{Bc}}$ & $5.0 \pm 0.1^{\mathrm{Ef}}$ & $6.0 \pm 0.1^{\mathrm{Dd}}$ & $11.0 \pm 0.1^{\mathrm{Ab}}$ & $8.0 \pm 0.1^{\mathrm{Cc}}$ \\
\hline & & $\mathrm{Oz}_{10}$ & $7.0 \pm 0.3^{\mathrm{Ce}}$ & $5.0 \pm 0.1^{\mathrm{Ee}}$ & $8.0 \pm 0.1^{\mathrm{Ba}}$ & $9.0 \pm 0.1^{\mathrm{Ad}}$ & $7.0 \pm 0.4^{\mathrm{De}}$ \\
\hline & & $\mathrm{Oz}_{20}$ & $6.0 \pm 0.1^{\mathrm{Cf}}$ & $6.0 \pm 0.1^{\mathrm{Dc}}$ & $9.0 \pm 0.2^{\mathrm{Ba}}$ & $9.0 \pm 0.2^{\mathrm{Ac}}$ & $6.0 \pm 0.1^{\mathrm{Cf}}$ \\
\hline
\end{tabular}

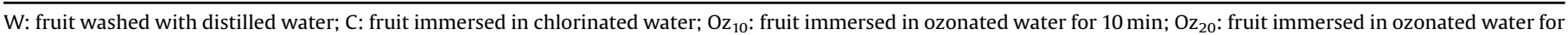
20 min. AA: Ascorbic Acid; DHAA: Dehydroascorbic Acid; TP: Total Polyphenols. n.d. not detected.

The means followed by the same capital letters (lines) and case letters (column) were not statistically significant according to the Scott-Knott's test ( $\mathrm{*} \leq 0.05$ ).

Ozonated water used as sanitizer did not cause a decrease in $\beta$-carotene content when the fruit were stored in the cold chamber until $7 \mathrm{~d}$ (Table 2 ). On the 15 th $\mathrm{d}$ in cold storage, the conventional mangoes had higher $\beta$-carotene levels than the organic ones, except for those that had been immersed in ozonated water for $10 \mathrm{~min}$. The concentration of carotenoids generally increased exponentially with ripening (Ornelas-Paz et al., 2008), and the firmness decayed during ripening, which paralleled the degradation in chlorophyll and the carotenoid accumulation; all of these processes are dependent on ethylene (Eccher Zerbini et al., 2015). Mango is a climacteric fruit and therefore produces ethylene (White, 2002). After this process, the levels tend to stagnate or decrease during storage, depending on the temperature used (Liu et al., 2009) or on the sanitation treatment, such as ozone (Ölmez and Kretzschmar, 2009).

In our study, there were no variations in the $\beta$-carotene content during cold storage, but when the mango, cv. Palmer was moved to room temperature, the results were interesting, similar to what happened to the levels of AA. Therefore, at the last day, the $\beta$-carotene content showed no decrease. It is possible that the storage temperature used for the organic and conventional mangoes induced changes in carotenoid biosynthesis and accumulation. Some studies have shown that the increase in $\beta$-carotene content may be related to the intense yellow coloration in the mango pulp of different cultivars (Ornelas-Paz et al., 2008; Ibarra-Garza et al., 2015). The highest $\beta$-carotene level (323.34 $\mathrm{mg} \mathrm{kg}^{-1}$ ) was found in the pulp of the organic fruit stored for $7+8 d$ and treated with ozonated water for $20 \mathrm{~min}$, although these fruit showed advanced senescence and were unsuitable for fresh consumption. Other authors have described an increase in the content of this compound in mangoes at the end of the storage period (Ibarra-Garza et al., 2015).

The use of ozonated water did not promote an increase in the total phenols in mangoes maintained in a cold chamber (Table 2) until $7 \mathrm{~d}$. When mangoes were transferred to room temperature and kept for $8 \mathrm{~d}(7+8 \mathrm{~d})$, treatment with ozonated water did not induce an increase in the content of total phenols, regardless of the type of cultivation. Some researchers have asserted that exposure to ozone increases total phenol content (Alothman et al., 2010; Yeoh et al., 2014) due to changes in the enzyme activities, such as phenylalanine ammonia-lyase (PAL) and peroxidase (POD)

(Chauhan et al., 2011). However, this effect was not observed in the mangoes sanitized with ozonated water.

Mango is a climacteric fruit, which exhibits a rise in ethylene biosynthesis with concomitant increases in respiration rate (White, 2002). All of these processes induce degradative metabolism and hence the formation of reactive oxygen species (ROS) (Ibarra-Garza et al., 2015). To combat possible damage caused by ROS, cells can increase the synthesis of compounds antioxidants such as polyphenols (Palafox-Carlos et al., 2012). Thus, the increase observed after the fruit were taken to the elevated shelf temperature environment $(7+4 \mathrm{~d})$ can be attributed to the formation of ROS and the action of an effective antioxidant 
Table 3

Antioxidant capacity during the postharvest of organic and conventional mango, $\mathrm{cv}$. Palmer sanitized with chlorine or ozonated water ( $\mathrm{n}=\mathrm{X} \pm \mathrm{SD}$ ).

\begin{tabular}{|c|c|c|c|c|c|c|c|}
\hline & & \multirow[t]{2}{*}{ Treatments } & \multirow[t]{2}{*}{ Post harvest } & \multicolumn{2}{|c|}{ Cold storage (days postharvest) } & \multicolumn{2}{|c|}{ Simulated marketing (days postharvest) } \\
\hline & & & & 7 & 15 & $7+4$ & $7+8$ \\
\hline \multirow[t]{8}{*}{ DPPH $\left(\mu \mathrm{mol} \mathrm{kg}^{-1}\right)$} & Conv & $\mathrm{W}$ & $7.20 \pm 0.50^{\mathrm{Bb}}$ & $8.40 \pm 0.45^{\mathrm{Ab}}$ & $8.40 \pm 0.15^{\mathrm{Aa}}$ & $5.10 \pm 0.78^{\mathrm{Cd}}$ & $7.00 \pm 0.43^{\mathrm{Ba}}$ \\
\hline & & $\mathrm{C}$ & $5.00 \pm 0.05^{\mathrm{Cc}}$ & $7.10 \pm 0.26^{\mathrm{Bc}}$ & $8.80 \pm 0.66^{\mathrm{Aa}}$ & $6.40 \pm 0.28^{\mathrm{Bb}}$ & $6.80 \pm 0.31^{\mathrm{Ba}}$ \\
\hline & & $\mathrm{Oz}_{10}$ & $5.20 \pm 0.40^{\mathrm{Cc}}$ & $6.80 \pm 0.29^{\mathrm{Bc}}$ & $8.34 \pm 0.44^{\mathrm{Aa}}$ & $4.50 \pm 0.66^{\mathrm{Cd}}$ & $4.90 \pm 0.26^{\mathrm{Cb}}$ \\
\hline & & $\mathrm{Oz}_{20}$ & $4.80 \pm 0.68^{\mathrm{Cc}}$ & $8.90 \pm 0.10^{\mathrm{Aa}}$ & $6.64 \pm 0.41^{\mathrm{Bb}}$ & $7.23 \pm 0.35^{\mathrm{Ba}}$ & $7.20 \pm 0.63^{\mathrm{Ba}}$ \\
\hline & Org & $\mathrm{W}$ & $8.70 \pm 0.60^{\mathrm{Aa}}$ & $8.00 \pm 0.76^{\mathrm{Bb}}$ & $9.10 \pm 0.22^{\mathrm{Aa}}$ & $5.70 \pm 0.39^{\mathrm{Cc}}$ & $1.10 \pm 0.45^{\mathrm{Dc}}$ \\
\hline & & $\mathrm{C}$ & $9.00 \pm 0.51^{\mathrm{Aa}}$ & $8.60 \pm 0.38^{\mathrm{Ab}}$ & $9.00 \pm 0.31^{\mathrm{Aa}}$ & $8.00 \pm 0.74^{\mathrm{Ba}}$ & $1.60 \pm 0.38^{\mathrm{Cc}}$ \\
\hline & & $\mathrm{Oz}_{10}$ & $8.50 \pm 0.84^{\mathrm{Ba}}$ & $9.40 \pm 0.19^{\mathrm{Aa}}$ & $9.33 \pm 0.02^{\mathrm{Aa}}$ & $6.31 \pm 0.25^{\mathrm{Cb}}$ & $6.72 \pm 0.83^{\mathrm{Ca}}$ \\
\hline & & $\mathrm{Oz}_{20}$ & $8.80 \pm 0.30^{\mathrm{Aa}}$ & $9.10 \pm 0.19^{\mathrm{Aa}}$ & $9.10 \pm 0.22^{\mathrm{Aa}}$ & $6.62 \pm 0.97^{\mathrm{Cb}}$ & $7.64 \pm 0.56^{\mathrm{Ba}}$ \\
\hline \multirow[t]{8}{*}{ FRAP $\left(\mathrm{mmol} \mathrm{kg}{ }^{-1}\right)$} & Conv & W & $20.37 \pm 3.03^{\mathrm{Ec}}$ & $27.19 \pm 2.23 \mathrm{Dc}$ & $60.29 \pm 1.56^{\mathrm{Ba}}$ & $83.96 \pm 0.63^{\mathrm{Ab}}$ & $48.90 \pm 3.38^{\mathrm{Ce}}$ \\
\hline & & $\mathrm{C}$ & $25.82 \pm 4.07^{\mathrm{Ec}}$ & $31.94 \pm 2.60^{\mathrm{Dc}}$ & $39.02 \pm 0.30^{\mathrm{Cc}}$ & $89.18 \pm 4.03^{\mathrm{Aa}}$ & $77.38 \pm 3.68^{\mathrm{Bb}}$ \\
\hline & & $\mathrm{Oz}_{10}$ & $21.70 \pm 0.65^{\mathrm{Ec}}$ & $28.11 \pm 2.34^{\mathrm{Dc}}$ & $61.11 \pm 0.32^{\mathrm{Ba}}$ & $79.75 \pm 1.37^{\mathrm{Ab}}$ & $53.90 \pm 0.75^{\mathrm{Cd}}$ \\
\hline & & $\mathrm{Oz}_{20}$ & $21.40 \pm 3.40^{\mathrm{Dc}}$ & $28.73 \pm 4.31^{\mathrm{cc}}$ & $50.37 \pm 3.04^{\mathrm{Bb}}$ & $60.72 \pm 3.76^{\mathrm{Ad}}$ & $46.28 \pm 2.94^{\mathrm{Be}}$ \\
\hline & Org & $\mathrm{W}$ & $53.43 \pm 3.86^{\mathrm{Ca}}$ & $48.32 \pm 7.3^{\mathrm{Cb}}$ & $49.42 \pm 0.24^{\mathrm{Cb}}$ & $92.76 \pm 7.43^{\mathrm{Aa}}$ & $67.46 \pm 6.93^{\mathrm{Bc}}$ \\
\hline & & $\mathrm{C}$ & $24.24 \pm 3.09^{\mathrm{Dc}}$ & $49.60 \pm 2.7^{\mathrm{Cb}}$ & $51.63 \pm 3.89^{\mathrm{Cb}}$ & $74.03 \pm 1.40^{\mathrm{Ac}}$ & $59.04 \pm 2.45^{\mathrm{Bd}}$ \\
\hline & & $\mathrm{Oz}_{10}$ & $38.93 \pm 2.83^{\mathrm{Db}}$ & $51.29 \pm 6.95^{\mathrm{Cb}}$ & $50.69 \pm 3.89^{\mathrm{Cb}}$ & $80.66 \pm 8.96^{\mathrm{Ab}}$ & $58.13 \pm 2.62^{\mathrm{Bd}}$ \\
\hline & & $\mathrm{Oz}_{20}$ & $48.45 \pm 1.27^{\mathrm{Ca}}$ & $60.47 \pm 4.71^{\mathrm{Ba}}$ & $51.21 \pm 2.65^{\mathrm{Cb}}$ & $57.85 \pm 3.70^{\mathrm{Bd}}$ & $84.83 \pm 1.54^{\mathrm{Aa}}$ \\
\hline
\end{tabular}

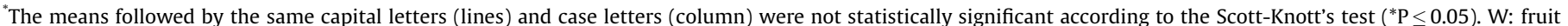

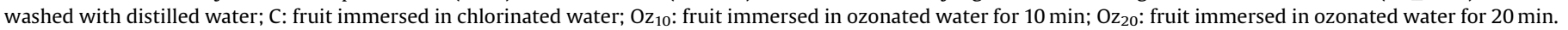

system, such as found in this study with mango, cv. Palmer and also described for mangoes, cv. Keitt (Ibarra-Garza et al., 2015).

There was a tendency for the organically cultivated mangoes to show higher levels of antioxidant activity measured by DPPH after harvest (Table 3). After $15 \mathrm{~d}$, this difference disappeared, except in fruit treated in ozonated water for $20 \mathrm{~min}$. At $7+8 \mathrm{~d}$, the organic and conventional mangoes treated with ozonated water for $20 \mathrm{~min}$ showed higher values of antioxidant activity. When the antioxidant activity was analyzed using FRAP (Table 3 ), the results were similar to the DPPH on harvest day as well as after $7 \mathrm{~d}$ in cold storage. On those days, there was a trend for the organic mangoes to show higher antioxidant activity, however that tendency disappeared after $15 \mathrm{~d}$ of storage in the cold chamber. In other studies, ozone induced an increase in antioxidant activity measured by DPPH in fruits and vegetables (González-Aguilar et al., 2007; Alothman et al., 2010; Yeoh et al., 2014). After $7 \mathrm{~d}$ in the cold chamber and $4 \mathrm{~d}$ at room temperature, the mango, cv. Palmer fruit showed higher antioxidant activity when we used the FRAP method. This result can be attributed to increases observed in TP (Table 3 ), regardless of the crop or sanitization method.

\subsection{Microbiological analyses}

On the day of harvest and after the treatments no Salmonella, thermotolerant coliforms or S. aureus were found (Table 4). According to Brazilian legislation (RDC-12, Brazil, 2001), it must not occur the presence of Salmonella in $25 \mathrm{~g}$ of fruit and vegetables (whole or fractionated) and the maximum content of coliforms at $45^{\circ} \mathrm{C}$ should be $102 \mathrm{CFU} \mathrm{g}^{-1}$.
Our results showed that water did not eliminate total coliforms from the conventional mangoes $(\mathrm{MPN}=240)$. At $7 \mathrm{~d}$ and $7+4 \mathrm{~d}$, these microorganism were observed in the conventional $(\mathrm{MPN}=23)$ and organic $(\mathrm{MPN}=43)$ mango, $\mathrm{cv}$. Palmer not sanitized with chlorine or ozonated water. Ozonated and chlorinated water were efficient at eliminating thermolerant coliforms during the storage. It was not observed the presence of Salmonella and $S$. aureus in mangoes, cv. Palmer, with or without sanitization during the storage in cold chamber or simulated marketing. Other studies have confirmed the efficiency of using ozone for sanitation (Karaca and Velioglu, 2007), as reported for broccoli (Lima et al., 2014) and papaya (Yeoh et al., 2014).

Because chlorine is not used on organic products, ozonated water was a good sanitizer for mango, cv. Palmer. Another important factor when using ozonated water is that the water can probably be reused. According to Ölmez and Kretzschmar (2009), ozone does not leave a residue and thus water can be recycled.

\section{Conclusion}

In this study using conventional and organic mango, a few variations were found in relation to compounds with antioxidant properties that have led us to state that organic mangoes contain higher quantities of bioactive compounds compared to conventional ones. Ozonated water can be used as an alternative to chlorine sanitizer without causing damage to mango, cv. Palmer; specifically, it did not cause a decrease in the levels of substances with antioxidant potential (ascorbic acid, dehydroascorbic acid,

Table 4

Microbial counts ( $\mathrm{MPN} \mathrm{g}^{-1}$ ) during the postharvest of organic and conventional mango, cv. Palmer sanitized with chlorine or ozonated water of mango, cv. Palmer.

\begin{tabular}{|c|c|c|c|c|c|c|c|c|c|c|}
\hline \multirow[t]{3}{*}{ Treatments } & \multicolumn{5}{|c|}{ Total coliforms $\left(\mathrm{MPN} \mathrm{g}^{-1}\right)$} & \multicolumn{5}{|c|}{ Thermotolerant coliforms $\left(\mathrm{MPN} \mathrm{g}^{-1}\right)$} \\
\hline & \multicolumn{5}{|c|}{ Cold storage (days postharvest) } & \multicolumn{5}{|c|}{ Simulated marketing (days postharvest) } \\
\hline & 0 & 7 & 15 & $7+4$ & $7+8$ & 0 & 7 & 15 & $7+4$ & $7+8$ \\
\hline Org/Water & $<3$ & $4.3 \times 10^{1}$ & $<3$ & $9.1 \times 10^{1}$ & $<3$ & $<3$ & $<3$ & $<3$ & $<3$ & $<3$ \\
\hline Org/Chlorine & $<3$ & $<3$ & $<3$ & $<3$ & $<3$ & $<$ & $<3$ & $<3$ & $<3$ & $<3$ \\
\hline Org/Ozone $10^{\prime}$ & $<3$ & $<3$ & $<3$ & $<3$ & $<3$ & $<3$ & $<3$ & $<3$ & $<3$ & $<3$ \\
\hline Org/Ozone $20^{\prime}$ & $<3$ & $<3$ & $<3$ & $<3$ & $<3$ & $<3$ & $<3$ & $<3$ & $<3$ & $<3$ \\
\hline Conv/Water & $2.4 \times 10^{2}$ & $2.4 \times 10^{2}$ & $2.4 \times 10^{2}$ & $2.4 \times 10^{2}$ & $2.4 \times 10^{2}$ & $<3$ & $<3$ & $<3$ & $<3$ & $<3$ \\
\hline Conv/Chlorine & $<3$ & $<3$ & $<3$ & $<3$ & $<3$ & $<3$ & $<3$ & $<3$ & $<3$ & $<3$ \\
\hline Conv/Ozone $10^{\prime}$ & $<3$ & $<3$ & $<3$ & $<3$ & $<3$ & $<3$ & $<3$ & $<3$ & $<3$ & $<3$ \\
\hline Conv/Ozone $20^{\prime}$ & $<3$ & $<3$ & $<3$ & $<3$ & $<3$ & $<3$ & $<3$ & $<3$ & $<3$ & $<3$ \\
\hline
\end{tabular}


$\beta$-carotene and total phenolic) and can be used with organic foods. The treatment using ozonated water effectively sanitized the mangoes, prevented a reduction in quality and avoided the generation of organic waste.

\section{Acknowledgements}

We would like to thank the "Conselho Nacional de Desenvolvimento Científico e Tecnológico" (CNPq) (CNPq-141354/2012-7; 478372/2013-2; 306151/2012-0; 305177/2015-0) and the "Fundação de Amparo à Pesquisa do Estado de São Paulo" (FAPESP) (2013/ 05644-3) for their financial support for this project.

\section{References}

Ölmez, H., Kretzschmar, U., 2009. Potential alternative disinfection methods for organic fresh-cut industry for minimizing water consumption and environmental impact. LWT: Food Sci. Technol. 42, 686-693. doi:http://dx.doi. org/10.1016/j.lwt.2008.08.001.

Aguayo, E., Escalona, V.H., Artés, F. 2006. Effect of cyclic exposure to ozone gas on physicochemical, sensorial and microbial quality of whole and sliced tomatoes. Postharvest Biol. Technol. 39, 169-177. doi:http://dx.doi.org/10.1016/j. postharvbio.2005.11.005

Ali, A., Ong, M.K., Forney, C.F., 2014. Effect of ozone pre-conditioning on quality and antioxidant capacity of papaya fruit during ambient storage. Food Chem. 142, 19-26. doi:http://dx.doi.org/10.1016/j.foodchem.2013.07.039.

Allende, A. Marín, A., Buendía, B., Tomás-Barberán, F., Gil, M.I., 2007. Impact of combined postharvest treatments (UV-C light, gaseous O3, superatmospheric $\mathrm{O} 2$ and high $\mathrm{CO} 2$ ) on health promoting compounds and shelf-life of strawberries. Postharvest Biol. Technol. 46, 201-211. doi:http://dx.doi.org/ 10.1016/j.postharvbio.2007.05.007.

Alothman, M., Kaur, B., Fazilah, A., Bhat, R., Karim, A.A., 2010. Ozone-induced changes of antioxidant capacity of fresh-cut tropical fruits. Innov. Food Sci. Emerg. Technol. 11, 666-671. doi:http://dx.doi.org/10.1016/j.ifset.2010.08.008.

Benzie, I.F.F., Strain, J.J., 1999. Ferric reducing (antioxidant) power as a measure of antioxidant capacity: the FRAP assay. Methods Enzym. 299, 15-36.

Brand-Williams, W., Cuvelier, M.E., Berset, C., 1995. Use of a free radical method to evaluate antioxidant activity. LWT: Food Sci. Technol. 28, 25-30. doi:http://dx. doi.org/10.1016/S0023-6438(95)80008-5.

Brasil, 2000. Ministério da Agricultura, Pecuária e Abastecimento. Padrões de identidade e qualidade para polpa de manga, Brasília, Distrito Federal, 1018

Brazil, 2001. Ministério da Saúde. Agência Nacional de Vigilância Sanitária-ANVISA Resolução RDC-12/01, de 2 de janeiro de 2001, Diário Oficial [da] República Federativa do Brasil. Brasília, DF, 10 jan., 2001, Seção 1, p.45.

Chauhan, D.S., Deswal, D.P. Dahiya, D.P., Punia, R.C., 2011. Change in storage enzymes activities in natural and accelerated aged seed of wheat (Triticum aestivum). Indian J. Agric. Sci. 81, 1037-1040.

Eccher Zerbini, P., Vanoli, M., Rizzolo, A., Grassi, M., Pimentel, R.M., de, A., Spinelli, L., Torricelli, A., 2015. Optical properties, ethylene production and softening in mango fruit. Postharvest Biol. Technol. 101, 58-65. doi:http://dx.doi.org/ 10.1016/j.postharvbio.2014.11.008.

Embrapa, 1997. Manual de métodos de análises de solo, Empresa Brasileira de Pesquisa Agropecuária. 2nd Ed. Rio de Janeiro 212p.

González-Aguilar, G.A., Wang, C.Y., Buta, J.G., Krizek, D.T., 2001. Use of UV-C irradiation to prevent decay and maintain postharvest quality of ripe Tommy Atkins mangoes. Int. J. Food Sci. Technol. 767-773. doi:http://dx.doi.org/ 10.1046/j.1365-2621.2001.00522.x.

González-Aguilar, G.A., Zavaleta-Gatica, R., Tiznado-Hernández, M.E., 2007. Improving postharvest quality of mango Haden by UV-C treatment. Postharvest Biol. Technol. 45, 108-116. doi:http://dx.doi.org/10.1016/j. postharvbio.2007.01.012.

Hallmann, E., Rembial kowska, E., 2012. Characterisation of antioxidant compounds in sweet bell pepper (Capsicum annuum L.) under organic and conventional growing systems. J. Sci. Food Agric. 92, 2409-2415. doi:http://dx.doi.org $10.1002 /$ jsfa.5624.

Ibarra-Garza, I.P., Ramos-Parra, P.A., Hernández-Brenes, C., Jacobo-Velázquez, D.A., 2015. Effects of postharvest ripening on the nutraceutical and physicochemical properties of mango (Mangifera indica L. cv Keitt). Postharvest Biol. Technol.103, 45-54. doi:http://dx.doi.org/10.1016/j.postharvbio.2015.02.014.

Karaca, H., Velioglu, Y.S., 2007. Ozone applications in fruit and vegetable processing. Food Rev. Int. 23, 91-106. doi:http://dx.doi.org/10.1080/87559120600998221.

Kris-etherton, P.M., Hecker, K.D., Bonanome, A., Coval, S.M., Binkoski, A.E., Hilpert, K. F., 2002. Bioactive Compounds in foods: their role in the prevention of cardiovascular disease and cancer. Am. J. Chem. 113, 71.

Lee, S.K., Kader, A. a., 2000. Preharvest and postharvest factors influencing vitamin C content of horticultural crops. Postharvest Biol. Technol. 20, 207-220. doi: http://dx.doi.org/10.1016/S0925-5214(00)00133-2.

Li, L., Aldini, G., Carini, M., Chen, C.-Y.Y.O., Chun, H.-K.K., Cho, S.-M.M., Park, K.-M.M. Correa, C.R., Russell, R.M., Blumberg, J.B., Yeum, K.-J.J., 2009. Characterisation, extraction efficiency, stability and antioxidant activity of phytonutrients in Angelica keiskei. Food Chem. 115, 227-232. doi:http://dx.doi.org/10.1016/j. foodchem.2008.12.015.

Lima, G.P.P., Vianello, F., 2011. Review on the main differences between organic and conventional plant-based foods. Int. J. Food Sci. Technol. 46,1-13. doi:http://dx. doi.org/10.1111/j.1365-2621.2010.02436.x.

Lima, G.P.P., Machado, T.M., de Oliveira, L.M., da Silva Borges, L., de Albuquerque Pedrosa, V., Vanzani, P., Vianello, F., 2014. Ozonated water and chlorine effects on the antioxidant properties of organic and conventional broccoli during postharvest. Sci. Agric. 71, 151-156. doi:http://dx.doi.org/10.1590/s010390162014000200010.

Liu, L.H., Zabaras, D., Bennett, L.E., Aguas, P., Woonton, B.W., 2009. Effects of UV-C, red light and sun light on the carotenoid content and physical qualities of tomatoes during post-harvest storage. Food Chem. 115, 495-500. doi:http://dx. doi.org/10.1016/j.foodchem.2008.12.042.

Minas, I.S., Tanou, G., Belghazi, M., Job, D., Manganaris, G.A., Molassiotis, A., Vasilakakis, M., 2012. Physiological and proteomic approaches to address the active role of ozone in kiwifruit post-harvest ripening. J. Exp. Bot. 63, 24492464. doi:http://dx.doi.org/10.1093/jxb/err418.

Ornelas-Paz, J.D.J., Failla, M.L., Yahia, E.M., Gardea-Bejar, A., 2008. Impact of the stage of ripening and dietary fat on in vitro bioaccessibility of $\beta$-carotene in Ataulfo mango. J. Agric. Food Chem. 56, 1511-1516. doi:http://dx.doi.org/10.1021/ jf072751r.

Palafox-Carlos, H., Yahia, E.M., González-Aguilar, G.A., 2012. Identification and quantification of major phenolic compounds from mango (Mangifera indica, cv. Ataulfo) fruit by HPLC-DAD-MS/MS-ESI and their individual contribution to the antioxidant activity during ripening. Food Chem. 135, 105-111. doi:http://dx. doi.org/10.1016/j.foodchem.2012.04.103.

Pertuzatti, P.B., Sganzerla, M., Jacques, A.C., Barcia, M.T., Zambiazi, R.C., 2015. Carotenoids, tocopherols and ascorbic acid content in yellow passion fruit (Passiflora edulis) grown under different cultivation systems. LWT: Food Sci. Technol. 64, 259-263. doi:http://dx.doi.org/10.1016/j.lwt.2015.05.031.

Ribeiro, S.M.R., Barbosa, L.C.A., Queiroz, J.H., Knödler, M., Schieber, A., 2008. Phenolic compounds and antioxidant capacity of Brazilian mango (Mangifera indica L.) varieties. Food Chem. 110, 620-626. doi:http://dx.doi.org/10.1016/j. foodchem.2008.02.067.

Rodoni, L., Casadei, N., Concellón, A., Chaves Alicia, A.R., Vicente, A.R., 2010. Effect of short-Term ozone treatments on tomato (Solanum lycopersicum L.) fruit quality and cell wall degradation. J. Agric. Food Chem. 58, 594-599. doi:http://dx.doi. org/10.1021/jf9029145.

Singleton, V.L., Rossi, J.A.J., 1965. Colorimetry of total phenolics with phosphomolybdic-phosphotungstic acid reagents. Am. J. Enol. Vitic. 16, 144 158.

Tzortzakis, N., Borland, A., Singleton, I., Barnes, J., 2007. Impact of atmospheric ozone-enrichment on quality-related attributes of tomato fruit. Postharvest Biol. Technol. 45, 317-325. doi:http://dx.doi.org/10.1016/j. postharvbio.2007.03.004.

White, P.J., 2002. Recent advances in fruit development and ripening: an overview. J. Exp. Bot. 53, 1995-2000. doi:http://dx.doi.org/10.1093/jxb/erf105.

Yeoh, W.K., Ali, A., Forney, C.F., 2014. Effects of ozone on major antioxidants and microbial populations of fresh-cut papaya. Postharvest Biol. Technol. 89, 56-58. doi:http://dx.doi.org/10.1016/j.postharvbio.2013.11.006. 